\title{
PEMAHAMAN MANASIK HAJI DI KALANGAN PERSIS PERSPEKTIF LIVING HADIS
}

\author{
Agung Danarta, Indal Abror \\ UIN Sunan Kalijaga Yogyakarta \\ Email:agung.danarta@uin-suka.ac.id,
}

\begin{abstract}
:
Hajj rituals are considered important as a way for the Hajj to be carried out successfully. The PERSIS as a social organization considers the need for the implementation of this ritual. However, there is a surprising phenomenon related to the 2015 Mina tragedy in which data shows that of 34 people who died, 17 were from the PERSIS congregation. This paper aims to explain the understanding of the hadith "take from me the rituals of Haj)" according to PERSIS congregation, and how the implications of that understanding are in the context of the Hajj for them. With the approach of the living hadith, this study found that even though they had followed the Hajj rituals, most of them had never performed the Hajj and or Umrah. Hajj rituals need to be done so that the Hajj procession can be carried out according to what was exemplified by the Prophet. KBIH plays a significant role in providing knowledge to prospective pilgrims about the actual reality of Hajj. This study shows that based on the living hadith approach, it is deemed necessary for the management of the Hajj rituals thus that the Hajj can run comfortably, and the pilgrims can return safely and soundly.
\end{abstract}

Keywords: Hajj rituals; PERSIS; living hadith; management of Hajj rituals.

\section{Abstrak :}

Ritual haji dianggap penting sebagai cara untuk melaksanakan ibadah haji dengan sukses. PERSIS sebagai organisasi sosial mempertimbangkan perlunya pelaksanaan ritual ini. Namun, ada fenomena mengejutkan terkait dengan tragedi Mina 2015 di mana data menunjukkan bahwa dari 34 orang yang tewas, 17 berasal dari jama'ah PERSIS. Makalah ini bertujuan untuk menjelaskan pemahaman hadits 
"ambil dari saya ritual haji” menurut jamaah PERSIS, dan bagaimana implikasi dari pemahaman itu dalam konteks haji bagi mereka. Dengan pendekatan hadits yang hidup, penelitian ini menemukan bahwa meskipun mereka telah mengikuti ritual haji, kebanyakan dari mereka belum pernah melakukan haji dan atau umrah. Ritual haji perlu dilakukan agar prosesi haji dapat dilakukan sesuai dengan apa yang dicontohkan oleh Nabi. KBIH memainkan peran penting dalam memberikan pengetahuan kepada calon jamaah haji tentang realitas aktual haji. Penelitian ini menunjukkan bahwa berdasarkan pendekatan hadits yang hidup, maka dipandang perlu untuk pengelolaan ritual haji sehingga haji dapat berjalan dengan nyaman, dan jamaah dapat kembali dengan aman dan sehat.

Kata Kunci: manasik haji, PERSIS, living Hadis, manajemen manasik haji.

\section{Pendahuluan}

Haji merupakan salah satu rukun Islam dan keberadaannya berbeda dengan rukun Islam lainnya karena adanya persyaaratan istita'ah (mampu). ${ }^{1}$ Yang dimaksud dengan kemampuan dalam hal ini adalah menyangkut dalam hal materi, fisik dan pemahaman tentang haji. Namun, kebanyakan ibadah haji adalah fisik dan di lakukan di Negara Arab Saudi yang suhu udaranya cenderung panas dibandingkan Indonesia. Ritual-ritual haji paling tidak dilakukan di Arafah, Mina dan Muzdalifah atau dikenal dengan Armina yang dilakukan tanggal 8-14 Zulhijjah dalam setiap tahunnya. ${ }^{2}$ Selain Armina, ritual haji juga dilakukan di Makkah al-Mukarramah tepatnya di Masjid al-Haram yakni tawaf ifadhah dan sa'i.

Perkembangan zaman sejak Islam datang dan disyariatkannya Haji hingga sekarang telah menimbulkan berbagai problem. Salah satunya adalah dengan banyaknya animo calon haji yang terus meningkat dalam setiap tahunnya. Sehingga ummat Islam sekarang rela mengantri bertahun-tahun untuk dapat menjalankan ibadah haji secara reguler. Selain itu, problem banyaknya haji juga berimplikasi pada jalannya pelaksanaan ibadah haji. Salah satu opersolan yang sudah terselesaikan adalah masalah perluasan Mina dengan pembuatan Mina Jadid yang dapat secara sah dijadikan tempat mabit dalam melaksanakan ibadah lempar jumrah. ${ }^{3}$

${ }^{1}$ Lihat Q.S. Ali Imran (3): 37.

${ }^{2}$ Haji dilakukan pada bulan-bulan tertentu, khususnya Zulhijjah sementara umrah dilakukan kapanpun tanpa adanya batasan waktu. Adanya hajji terbatas dengan kegiatan wukuf di Arafah yang dilakukan pada tanggal 9 Zulhijjah dan rentetan setelahnya.

${ }^{3}$ Sejarah perluasan Mina dengan Mina Jadid dilakukan tahun 1985 dan pada awalnya banyak yang menolak keberadaan Mina Jadid tersebut karena sudah dekat dengan Muzdalifah. Namun, seiring dengan banyaknya jamaah haji dan perkembangan waktu, upaya pemahaman Mina Jadid dengan Mina adalah sama dan tidak ada bedanya. 
Persoalan kekinian adalah dengan banyaknya korban tragedi Mina yang menelan lebih dari 800 orang jamaah haji. ${ }^{4}$ Masalah lempar jumrah merupakan masalah yang selalu muncul hal ini terkait erat dengan waktu utama dalam melakukan lempar jumrah. Walaupun sebenarnya, di setiap maktab selalu dibuat jadwal dalam melempar jumrah, namun sering diabaikan jamaah karena adanya pandangan melempar jumrah harus sesuai dengan yang dilakukan Nabi saw. Upaya pemahaman seperti tersebut nampaknya sekarang masih ada dan dilakukan oleh jamaah haji Indonesia dengan adanya korban Mina yang banyak dari Persis.

Persis merupakan organisasi sosial keagamaan yang berkembang di masyarakat khususnya di Bandung. ${ }^{5}$ Kehadirannya adalah dilatarbelakangi adanya Islam yang tidak murni dan oleh karenanya Persis ingin mengembalikan ajaran Islam sesuai ajaran dalam al-Qur'an dan hadis. Dalam visi organisasi adalah terwujudnya organisasi sesuai dengan tuntunan al-Qur'an dan sunnah dan dijabarkan dalam misi jihad adalah mengembalikan kehidupan umat pada al-Qur'an dan hadis, menghidupkan tauhidullah, ruhul jihad, ijtihad, dan tajdid. Mewujudkan muwahhid, mujahid dan mujaddid serta meningkatkan kualitas sumber daya dan kesejahteraan ummat. ${ }^{6}$

Persaolan akan muncul ketika pada masa kenabian, jumlah jamaah haji tidak sebanyak sekarang dan terjadinya berbagai tragedi kemanusiaan yang menjadikan ketidaknyamanan dalam pelaksanaan ibadah haji. Hal ini akan perlu meninjau kembali terkait pemahaman hadis ambillah dari ku (Nabi Muhammad saw.) manasik haji. Penelitian ini akan mencoba mengkaji tentang living hadis tentang pemahaman di kalangan Persis Bandung tentang pelaksanaan manasik ibadah haji yang sesuai dengan ajaran dalam al-Qur'an maupun hadis tersebut.

Persoalan yang menjadi fokus penelitian ini adalah persoalan yang terkait masalah haji yang dipahami oleh sekelompok organisasi masyarakat yang dikenal dengan Persatuan Islam (PERSIS). Hal ini terkait erat dengan banyaknya korban

${ }^{4}$ Data terakhir dari Kemenag RI, jumlah korban Mina adalah 124 orang jamaah haji Indonesia dan 5 WNI. Lihat http://www.kemenag.go.id/index.php?a=berita\&id=301053

${ }^{5}$ Didirikan oleh H. Zamzam dan Muhammad Yunus di Bandung Jawa Barat tanggal 12 September 1923. Berawal dari kelompok pengajian dan kemudian dikembangkan oleh A. Hassan dan Muhammad Natsir. Lihat Dakwah Ormas Islam 39-46. Yusuf Arsy (ed.) Gerakan Dakwah Islam dalam Perspektif Kerukunan Ummat Beragama, Badan Litbang dan Diklat Keagamaan Kemenag RI, 2012, 39-48. Kini Persis tidak hanya di Bnadung tapi juga di Bangil Jawa Timur, 257.

${ }^{6}$ Lihat Iwan Koswara, Eksistensi Persatuan Islam dalam Penyebaran Paham Keagamaan dalm Jurnal AcadiumA, Vol. 10, No. 2, 2014, 3-33, h.19. Dalam ibadah, termasuk haji maka Persis lebih cenderung mencontoh Nabi saw. Haidlor Ali Ahmad, Sahri dan R. Adang Novandi, "Dakwah Nahdlatul Ulama, Muhammadiyyah dan Persatuan Islam di Kota Surabaya Profinsi Jawa Timur", dalam Yusuf Arsy (ed.) Gerakan Dakwah Islam dalam Perspektif Kerukunan Ummat Beragama, Badan Litbang dan Diklat Keagamaan Kemenag RI, 2012, h. 277. 
tragedi Mina tahun 2015 yang berasal dari Jamaah calon Haji Persis Bandung. Berbagai penelitian tentang masalah haji sudah pernah dilakukan antara lain, penelitian terutama terkait erat dengan manajemen haji maupun yang lainnya. Seperti yang dilakukan oleh Abdul Hamid dengan penelitiannya tentang Kemungkinan Berhaji di Luar Zulhijjah dalam Perspktif Qat'iy dan Zhanni. ${ }^{7}$ Dalam tulisan tersebut dijelaskan tentang tidak mungkinnya pelaksanaan ibadah haji di luar Zulhijjah.

Penelitian lain terkait haji adalah terhadap haji dan kegairahan ekonomi. Dalam penelitinnya M. Sultoni, ${ }^{8}$ memaparkan makna haji di kalangan pedagang Beringharjo Yogyakarta di mana kaum pedagang memiliki pemaknaan yang relatif berbeda terhadap ibadah pelaksanaan haji.

Selanjutnya, Siti Yuliana dalam penelitiannya membahas tentang peranan Departemen Agama dalam penyelenggraan ibadah haji di kabupaten Madiun. ${ }^{9}$ Khususnya mengenai sosialisasi informasi pelayanan ibadah haji kepada masyarakat muslim bagi yang berminat menunaikan ibadah haji yaitu yang meliputi Pendaftaran Ibadah Haji, Biaya Penyelenggaraan Ibadah Haji (BPIH), Pelayanan Kesehatan, dan Pembimbingan Manasik Ibadah Haji kepada para calon jama'ah haji di tanah air.

Selain itu, Ika Setia Ningsih dalam sebuah penelitian menjelaskan adanya pengaruh bagi jamaah haji yang latihan senam haji dalam peningkatan daya tahan tubuh khususnya pada jantung dan paru bagi jamaah haji non resiko tinggi. ${ }^{10}$ Oleh karenanya latihan senam haji terbukti bermanfaat secara signifikan dalam meningkatan daya tahan jantung paru pada calon jamaah haji non-resiko tinggi secara signifikan. Dalam hal pelaksanaan ibadah haji terutama kaitannya dengan $\mathrm{KBIH}$, terdapat sebuah penelitian di mana dilakukan oleh Sulaiman. ${ }^{11}$ Dari penjelasan di atas, maka penelitian tentang Persis kaitannya dengan tragedi Mina yang berimplikasi atas pemahaman hadis "huzu anni manasikakum" belum ada yang melakukan penelitian. Penelitian ini merupakan sesuatu yang

\footnotetext{
${ }^{7}$ Lihat Abdul Hamid, Kemungkinan Haji di Luar Bulan Zulhijjah dalam Perspektif Qat'i dan Zanni Jurnal Penelitian Vol. 11 No. 1 Mei 2014, h. 20-40.

${ }^{8}$ Lihat M. Sultoni, Haji dan Kegairahan Ekonomi: Menguak Makna Ibadha Haji bagi Pedagang Muslim di Yogyakarta, Jurnal Penelitian Vol. 9 No. 1 Mei 2012, h. 49-65.

${ }_{9}^{9}$ Lihat Siti Yuliana, Peranan Departyemen Agama dalam Penyelenggaran Ibadha Haji Kabupaten Madiun: Studi Deskriptif Kualitatif tentang peranan Departemen Agama dalam tahun penyelenggaraan haji tahun 2007/2009, Fispol, Universitas Sebelas Maret 2009.

${ }^{10}$ Lihat Ika Setia Ningsih, Pengaruh Latihan Senam Haji terhadap Peningkatan Daya Tahan Jantung dan Paru pada Calon Jamaah Haji Non Resiko Tinggi, Jurnal Fisioterapi Indonusa Vol. 5 No. 2 Oktober 2005, 45-50.

${ }^{11}$ Lihat Sulaiman, Kepuasan Jamaah Haji terhadap Pelayanan KBIH di Kabupaten Jepara, Jurnal Analisa Vol. 21 No. 1 Juni 2013, 51-82.
} 
baru apalagi penelitian ini terkait erat dengan living hadis, di mana memaknai pemahaman Persis atas hadis Nabi saw. tersebut dalam masalah manasik haji khususnya masalah lempar jamarat di Mina.

Berdasarkan latar belakang di atas, penelitian ini akan mengkaji persoalan berikut: bagaimana pemaknaan hadis tentang ambillah dariku manasik haji di kalangan Persis? Dan bagaimana implikasi pemahaman tersebut dalam konteks pelaksanaan haji di era kekinian?

\section{Tentang Living Hadis}

Apa yang telah dipraktikkan oleh suatu komunitas beragama (umat Islam) dari ajaran-ajaran agamanya pada gilirannya akan menjadi tradisi dan budaya. ${ }^{12}$ Budaya dan tradisi keagamaan tentunya tidak selalu sama seperti yang dipraktikkan pada masa awal Islam. Perbedaan ruang dan waktu (space and time) dapat menjadi sebab adanya interpretasi dan penyesuaian. ${ }^{13}$ Namun tidak hanya sampai di situ, pada taraf tertentu praktik keagamaan bisa saja menyimpang (deviasi) dari prinsip-prinsip fundamental agama itu sendiri.

Fenomena praktik-praktik di masyarakat yang muncul dari pemahaman keagamaan dapat menjadi wilayah kajian tersendiri.Sampai di sini, yang menjadi objek bukan lagi teks-teks al-Qur'an maupun hadis, tetapi pola-pola prilaku masyarakat Islam yang muncul dari pemahaman mereka terhadap teks-teks tersebut.Al-Qur'an dan hadis tidak lagi sesuatu yang diam (silent) dan tertulis (written) dalam lembaran-lembaran mushaf dan kumpulan-kumpulan kitab hadis. Keduanya adalah apa yang dipraktikkan dan dimanifestasikan dalam kehidupan masyarakat Islam. Upaya untuk melakukan kajian tentang fenomena keagamaan masyarakat Islam memberikan istilah yang khas, yaitu living alQur'an dan living hadis. Istilah ini dapat didefinisikan sebagai fenomena yang berupa pola-pola prilaku masyarakat Islam yang muncul dari pemahaman mereka terhadap al-Qur'an dan hadis.

${ }^{12}$ Kepercayaan dipandang sebagai bagian dari unsur kebudayaan. Lihat definisi kebudayaan oleh E. B. Tylor dalam Soerjono Soekanto, Sosiologi Suatu Pengantar (Jakarta: RajaGrafindo Persada, 2002), 172.

${ }^{13}$ Kita tentu masih ingat dengan istilah living sunnah yang dikemukakan Fazlur Rahman. Bahwa setelah Nabi wafat, sunnah tidak hanya mencakup sunnah Nabi, tetapi juga termasuk interpretasi terhadap sunnah Nabi itu sendiri. Hal ini menunjukkan bahwa fase ruang dan waktu yang berbeda menjadi sebab adanya interpretasi. Lihat Fazlur Rahman, Islamic Methodology in History (Karachi: Central Institute of Islamic Research, 1965), 6. Juga lihat Fazlur Rahman, 'concept Sunnah, Ijtihad and Ijma' in the Early Period', Islamic Studies, 1, 1 (1962), 5-21. Dikutip dari Abdullah Saeed, 'Fazlur Rahman: a Framework for Interpreting the Ethico-legal Content of the Qur'an', dalam Modern Muslim Intellectuals and the Qur'an, Suha Taji-Farouki (Ed.), (London: Oxford University Press, 2004), 55. 
Namun sebelumnya, perlu dijelaskan terlebih dahulu bahwa istilah living hadis di sini berbeda dengan istilah living sunnah yang pernah diungkapkan oleh Fazlur Rahman. Pengertian hadis dan sunnah di sini tidak bersifat equivalent atau interchangeable (dapat dipertukartempatkan). Living sunnah biasanya dihadapkan dengan istilah prophetic sunnah yang berarti 'warisan ideal dari aktivitas kenabian', sementara living sunnah adalah sunnah kenabian (prophetic sunnah) yang dielaborasi dan diinterpretasi secara kreatif ketika menemukan perubahan-perubahan, tantangan-tantangan dan kondisi-kondisi baru yang dihadapi oleh komunitas muslim. ${ }^{14}$ Sedangkan living hadis adalah istilah bagi suatu fenomena sosial-budaya yang bersumber dari pemaknaan terhadap teksteks hadis. Penelitian ini akan dibatasi pada kajian living hadis. Pemisahan antara living al-Qur'an dan living hadis terkesan sulit karena al-Qur'an sendiri adalah induk (mainordinat) dari hadis sebagai pelengkap dan penjelasnya (subordinat). Namun demikian, living hadis akan lebih memfokuskan pada fenomena keagamaan yang mungkin bersumber dari hadis.

Hadis yang hidup di tengah-tengah kehidupan sehari-hari masyarakat Islam bisa mewujud dalam bentuk yang beraneka ragam, yang bagi sebagian pemeluk Islam mungkin malah telah dianggap menyimpang dari ajaran-ajaran dasar agama Islam itu sendiri. Kajian living hadis lebih dekat dengan kajiankajian ilmu sosial-budaya seperti antropologi dan sosiologi. Di sini peneliti tidak mempersoalkan kebenaran sebuah pemahaman kandungan hadis atau perlakuan terhadapnya. Karena tujuan penelitian bukanlah 'mengadili' atau 'menilai' sebuah pemaknaan dan pengejawantahannya dalam kehidupan, tetapi memahami, memaparkan, dan menjelaskan gejala-gejala tersebut. ${ }^{15}$

Sebelum menempatkan pemaknaan hadis dan perwujudannya dalam kehidupan sehari-hari (livinghadis) sebagai objek kajian, perlu dipaparkan terlebih dahulu asumsi-asumsi paradigma antropologi hermeneutik atau antropologi interpretif sebagai landasan pemikiran untuk memperbincangkan gejala sosialbudaya keagamaan. Asumsi pertama sebagai asumsi dasar adalah bahwa manusia adalah animal symbolicum atau hewan yang mampu menggunakan, menciptakan dan mengembangkan simbol-simbol untuk menyampaikan pesan dari individu satu ke individu yang lain. Simbol di sini diartikan sebagai segala sesuatu yang dimaknai. Kemampuan memberi makna inilah yang membedakan manusia

\footnotetext{
${ }^{14}$ Fazlur Rahman, 'Concept Sunnah, 5-21.

${ }^{15}$ Landasan teori mengenai living hadis ini lebih merupakan adaptasi dari tulisan Heddy Shri Ahimsa-Putra, "Menafsir 'al-Qur'an yang Hidup', Memaknai al-Qur'anisasi Kehidupan: Perspektif Antropologi Budaya”, Makalah Seminar "Living Qur'an: Al-Qur'an sebagai Fenomena Sosial Budaya”, Yogyakarta, 13-15 Maret 2005, hlm. 8.
} 
dengan binatang dan membuat manusia kemudian mampu berbahasa.Bahasa merupakan sebuah sistem pemaknaan. ${ }^{16}$ Asumsi kedua, bahwa kemampuan simbolik atau kemampuan memberikan makna ini diwarisi oleh manusia secara genetis.Ini terlihat dengan adanya kemampuan berbahasa pada setiap manusia normal. Dengan kemampuan simbolik ini manusia tidak pernah lagi melihat segala sesuatu 'sebagaimana adanya', tetapi sebagai sesuatu yang telah diberi makna, karena segala sesuatu dalam kehidupan manusia selalu menjadi objek atau tujuan pemaknaannya. ${ }^{17}$ Asumsi ketiga, isi pemaknaan dan hasil pemaknaan bersifat budaya atau kultural. Kemampuan melakukan pemaknaan boleh dikatakan semacam 'wadah' atau 'kerangka pemikiran' yang diperoleh lewat keturunan, tetapi isi untuk memberikan, 'menempelkan' makna-makna, merupakan sesuatu yang didapat lewat kehidupan sosial, lewat proses sosialisasi dan enkulturasi. ${ }^{18}$

Manusia sebagai animal symbolicum bersifat universal, karena setiap manusia memiliki kemampuan dasar untuk menggunakan simbol-simbol. Meskipun demikian, simbol-simbol yang kemudian dikenalnya, digunakannya untuk berinteraksi dan membangun perangkat pemaknaannya bersifat kultural, yang berarti berbeda antara komunitas pemakai suatu bahasa dengan pemakai bahasa lainnya.Jadi perangkat simbol yang dimiliki tidak bersifat universal. ${ }^{19}$ Paradigma yang digunakan untuk kajian living hadis di antaranya adalah paradigma fenomenologi dan akulturasi. ${ }^{20}$

Haji dalam pandangan umat Islam merupakan suatu yang fenomenal di mana kegiatan ibadah ini membutuhkan biaya yang tidak sedikit dan di sisi sosial kemasyarakatan banyak dilakukan kegiatan yang mengiringinnya. Dalam kaitannya dengan konteks ke-Indonesiaan sebagaimana di jelaskan di atas, maka haji juga merupakan sebuah tradisi yang sangat terkait erat dengan fenomena di atas. Oleh karenanya, pemahaman ritual haji terdapat perkembangan walaupun dilakukan di negara asalnya.

\section{Sekilas Sejarah dan Perkembangan PERSIS}

Dalam pentas kehidupan berbangsa dan bernegara terdapat ormasy yang memiliki gerakan tajdid yakni Muhammadiyah (Yogyakarta), al-Irsyad (Jakarta)

${ }^{16}$ Ibid., 2.

17 Ibid.

${ }^{18}$ Ibid.

${ }^{19}$ Ibid., 3.

${ }^{20}$ Paradigma akulturasi dipakai untuk mengetahui proses dan hasil interaksi antara ajaranajaran yang ada dalam hadis dengan system kepercayaan atau budaya lokal dalam suatu masyarakat. Lihat Heddy Shri Ahimsa-Putra, “Menafsir 'al-Qur’an yang Hidup’, hlm. 9. 
dan PERSIS (Bandung). ${ }^{21}$ Banyaknya gerarkan kebangkitan Islam tersebut dimulai abad ke-20. Hal ini terkait erat dengan mulai lahir kesadaran nasional seiring mewujudkan cita-cita kemerdekaan bangsa Indonesia. ${ }^{22}$

PERSIS adalah sebuah ormas atau organisasi kemassyarakatan yang sangat popular di Bandung. Ketenaran ormasy di bumi Sunda ini merujuk para pendiri ormas ini yakni berasal dari Bandung dan beberapa etnis Palembang yang menetap di Bandung. Mereka ini adalah Haji Zam-zam dan Haji Muhammad Yunus. ${ }^{23}$ Di awalnya, PERSIS hanyalah sebuah gerakan keagamaan bermula dari pengajian kecil dengan perkumpulan orang yang berjumlah 20 orang. Mereka ini sangat militant dalam mengkaji Islam melalui sumkber ajaran Islam al-Qur'an dan Sunnah.

Adalah 12 September 1923 merupakan pendirian secara formal keberadaan ormas ini. ${ }^{24}$ Keberadaan ormasy ini merupakan sebuah bentuk ikhtiar memberikan corak yang berbeda dengan ormasy lainnya yakni melakukan pembaruan pemikiran Islam. Hal ini terjadi dikarenakan kondisi masyarakat yang hidup dalam kemandekan dalam berpikir dan merebaknya mistisisme serta adanya kemunduran akibat penjajahan Belanda.

Dari perkumpulan pengajian yang kecil sekitar 20 orang menjadi sebuah organisasi besar berdasarkan banyaknya minat atas masyarakat untuk ikut kajian yang diadakan Tokoh-tokoh PERSIS. Akhirnya, dari pengajian ini menjadi sebuah orgniasasi yang berkembang pesat yang memusatkan pemahaman ajaran al-Qur'an dan Sunnah. Bagi persis kembali kepada kedua sumber tersebut tidak hanya berlaku pada akidah dan ibadah saja melainkan dalam banyak hal termasuk politik Islam untuk memenangkan ideologi Islam. ${ }^{25}$

Dari peran PERSIS yang tidak saja dalam memahami ajaran Islam, termasuk mengkaji persoalan politik. Maka tidaklah mengherankan, jika PERSIS sebagai organisasi masyarakat sangat berperan besar dalam kehidupan berbangsa dan bernegara. Tokoh yang aktif dalam pentas perpolitikan nasional dari PERSIS adalah A. Hassan, M. Natsir, Muhammad Isa Anshari, KH.E. Abdurrahman dan KH. Abdul Latif. ${ }^{26}$ Tokoh-tokoh tersebut dikenal masyarakat luas dalam pengabdiannya di bidang percaturan politik nasional kala itu.

\footnotetext{
${ }^{21}$ L. Stoddart, Dunia Baru Islam (Jakarta: PAnitia Penerbit, 1996), 306.

${ }^{22}$ Deliar Noer, Gerakan Modern Islam di Indonesia 1900-1942 (Jakarta: LP3ES, 1985), 95.

${ }^{23}$ Dadan Wildan, Yang Da’I Politikus Hayat dan Perjuangan Lima Tokoh PERSIS (Bandung: Rosdakarya, 1997), 7.

${ }^{24}$ Pusat Pimpinan Persatuan Islam, Sejarah Singkat Persatuan Islam (PERSIS) (Bandung, PP Persis, t,th.), 5 .

${ }^{25}$ Isa Anshari, Manifestasi Persatuan Islam (Bandung: PP PERSIS, 1958), 24.

${ }^{26}$ Dadan Wildan Anas, dkk., Anatomi Gerakan Dakwah Persatuan Islam Indonesia dalam
} 
Setelah kemerdekaan, peran PERSIS dalam perpolitikan mulai menurun. Walaupun secara organisatoris, PERSIS dalam muktamar ke-7 di Bangil, setelah terpilihnya KH. Isa Anshory maka wajah PERSIS menjadi lebih akrah ke politik praktis. Bahkan Nama PERSIS juga pernah diwacanakan untuk diubah menjadi Jamaah Muslimin. ${ }^{27}$ Namun, keinginan ini banyak ditentang dan selanjutrnya dalam kepemimpinan KH.. E. Abdurrahman dipilih melalui referendum. Apa yang dilakukan KH. E. Abdurrahman sebaliknya dari ngagasan KH Isa Anshary yang lebih suka ke area non praktis. Hal ini dilalui PERSIS tahun 1962-1983. Kebijakannya menjadikan PERSIS sebagai gerakan tabligh dan pendidikan.

PERSIS dalam menjalankan misinya di bidang pendidikan sudah ditata dengan baik berikut kurikulum dalam pembelajarannya. Penataan ini terkait erat dari visi misi dan tujuan dari pendidikan PERSIS. Sekarang, sosok PERSIS lebih dkenal dalam bidang sosial keagamaan dengan memulai bidang usaha di sektor pendidikan baik formal maupun secara tradisional.

Untuk mendapatkan simpati masyarakat selain dalam hal pendidikan formal sebagaimana digagas di atas juga dilakukan melalui pertemuan-pertemuan keagamaan yang dilakukan sejak awal beridirnya ormasy ini. Demikian juga dalam hal pelaksanaan ibadah haji, PERSIS juga memiliki KBIH dalam rangka memberikan pengajaran kegamaan khususnya manasik haji yang dapat dijadikan bekal bagi anggota ormasy ini dalam menjalankan ibadah haji dan atau umrah.

Bidikan ibadah haji dan umrah ini seiring dnegan munculnya kesadaran masyarakat untuk menjalankan ibadah haji dan masa tunggu haji terlalu lama sehingga sebagian besar masyarakat menginginkan untukmelaksanakan ibadah umrah. Antara ibadah umrah dan haji ini dijadikan sebagai model dakwah dalam rangka menjadikan masyarakat akan faham sesuai ajaran Islam sebagaimana diajarkan oleh Nabi saw.

\section{PERSIS dan Manasik Haji}

Sebagaimana diketahui di atas, terhadap pendidian PERSIS sebagai organisasi sosial keagamaan yang bertujuan sebagai pemurnian ajaran Islam. Pola acuannya adalah al-Qur'an dan Sunnah yang sesuai dan diajarkan oleh Rasulullah saw. maka sosok PERSIS sebagai sebuah organaisasi masyarakat selalu mengajarkan doktrin keagamaan sesuai dengan misi tersebut.

\footnotetext{
https://www.academia.edu/27577975/ANATOMI_GERAKAN_DAKWAH_PERSATUAN_ ISLAM 233-252.

${ }^{27}$ Haris Muslim, Persis dari Masa ke Masa: Sebuah Refleksi Sejarah dalam Siapkah PERSIS menjadi Mujaddid lagi? Upaya Mewujudkan Wacana PERSIS Baru, dalam Yusup Burhanuddin (Bandung: Alqaprint, 2000), 28.
} 
Sebagai pembaru dalam ajaran Islam, PERSIS berupaya melaksanakan ajaran Islam sesuai yang diajarkan oleh Rasulullah saw. sebagaimana dalam alQur'an dan Hadis Nabi saw. Kedua sumber inilah yang dijadikan acuan dalam kehidupan keseharian termasuk di dalamnya dalam menunaikan ibadah haji dan umrah.

Pola pemahaman masyarakat PERSIS atas hadis Nabi sebagai ajaran Islam adalah dapat dilihat dalam tabel berikut:

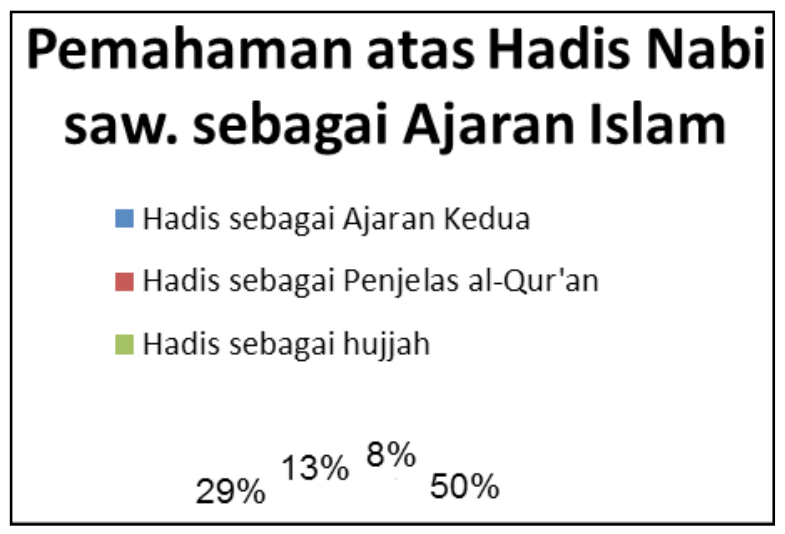

Secara umum, sosok masyarakat PERSIS mengakui fungsi al-Hadis dalam ajaran Islam. Dalam memahami hadis sebagai ajaran Islam mereka menempatkannya setelah al-Qur'an. Jumlah mereka ini sebanyak 60\%. Hal ini menunjukkan bahwa secara umum, pemahaman mereka atas hadis sebagai ajaran Islam sesuai dengan kaidah yang ada dan penjelasan Rasulullah saw. dalam konteks ini, mereka juga mempercayai akan fungsi hadis adalah untuk menjelaskan al-Qur'an. Dalam arti, hadis sebagai implementasi ajaran Islam yang dijelaskan secara global dalam al-Qr'an. Mereka memberikan contoh kegiatan peribadatan seperti shalat dan ibadah haji. Dalam al-Qur'an kedua perintah tersebut dijelaskan secara kewajiban saja namun aplikasi pelaksanaannya dijelaskan Rasulullah saw. melalui hadis-hadisnya, terutama hadis fi'li atau hadis perbuatan Nabi saw.

Demikian juga, pemahaman yang berbeda adalah mereka juga memahami bahwa hadis itu memiliki fungsi utama dapat dijadikan aturan pokok jika dalam al-Qur'an tidak ada penjelasan. Selain itu, mereka yang menjawab 10\% dari keseluruhan memberikan jawaban bahwa sosok Muhammad saw. dapat dijadikan suritauladan dalam kehidupan keseharian tidak hanya pada persoalan peribadatan saja melainkan juga pada aspek akhlak atau hubungan manusia sesama manusia dan lainnya. 
Pemahaman atas persoalan ibadah haji dikalangan mereka yang sedang dan akan menjalankan ibadah haji dan telah menjalankan ibadah haji adalah sebagai berikut:

\section{Pemahaman atas Haji sebagai Rukun Islam}

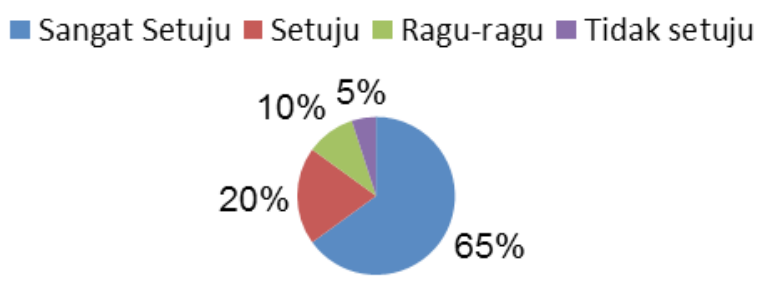

Secara umum, pemahaman atas haji sebagai rukun Islam adalah mereka memahaminya dengan baik. Setidaknya, sebanyak $65 \%$ di antara mereka memahami sangat baik akan hal ini. Adapun selebihnya adalah $20 \%$ dengan memahami secara baik. Sebagaimana diketahui, bahwa pemahaman mereka ini didasarkan atas hadis berikut:

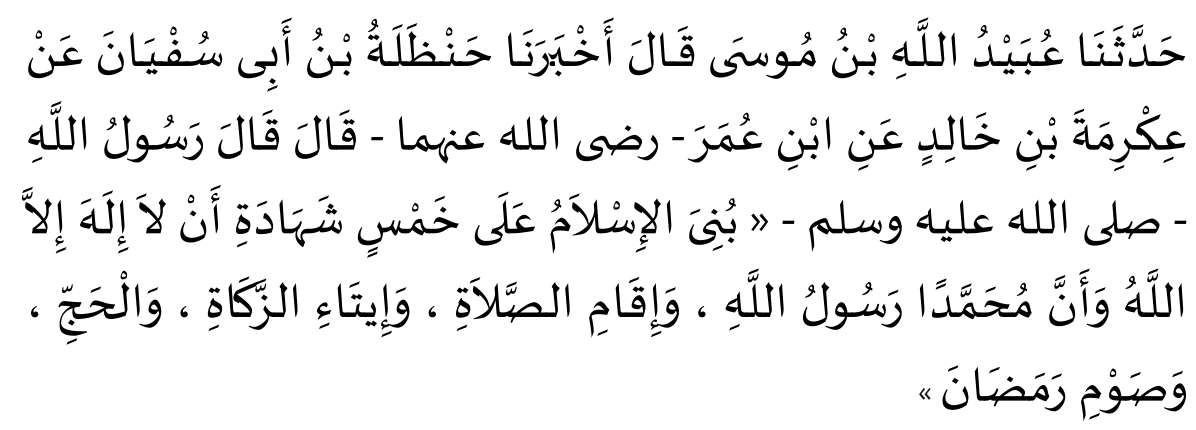

Dari hadis di atas, mereka memahami ajaran rukun Islam dengan baik. Termasuk di dalamnya, mereka memahami bahwa haji adalah bagian dari rukun Islam. Sedangkan bagi yang pemahamannya kurang yang jumlahnya hanya $5 \%$ ini merupakan sesuatu yang lumrah. Mereka yang pemahamannya kurang atau ragu-ragu adalah mereka yang sifatnya pengikut saja tidak dalam kategori melaksanakan sesuatu dnegan mengetahuinya. Orang yang seperti ini adalah mereka yang pendidikannya tidak tinggi atau hanya mengenyam pendidikan dasar saja.

Sementara ragam pemahaman atas pelaksanaan haji adalah sebagai berikut: 


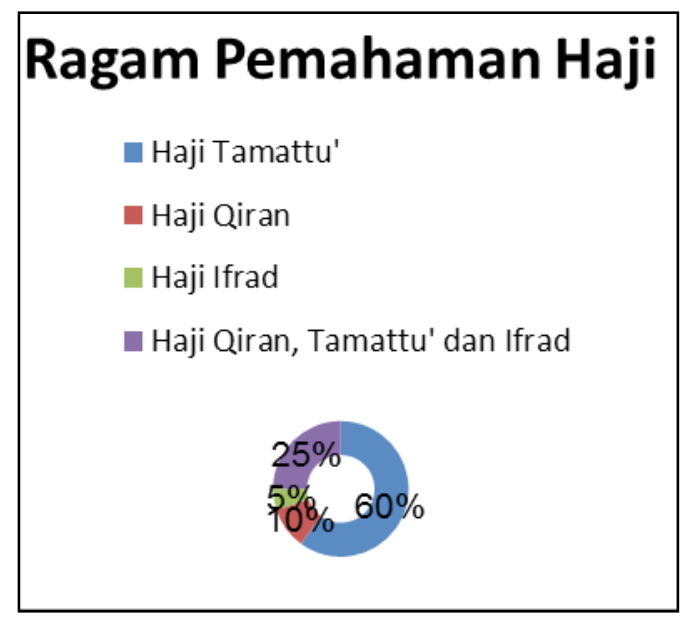

Secara umum pemahaman yang diberikan dan diketahui masyarakat PERSIS adalah hajji tamattu'. Karena bentuk haji inilah ytang sangat dianjurkan karena lebih mudah dan fleksibel dalam pelaksanannya, yakni umrah dulu baru menjalankan ibadah haji. Mereka ini lebih suka melaksanakan seperti ini. Sementara $20 \%$ di antara mereka ada yang memahami ketiga bentuk haji. Bagi, mereka untuk melaksanakan ibadah haji tergantung dengan kebutuhan dan keberangkatan ke Saudi Arabia. Bagi mereka yang datanagnya mendekati pelaksanaan ibadah haji, maka sebaiknya melaksanakan ibadah haji dan setelahnya umrah dan atau bersamaan antara haji dan umroh.

Bagi jamaah PERSIS ini sebagian besar memahami perbedaan antara haji dan umrah. Pemehaman mereka tentang hal ini adalah:

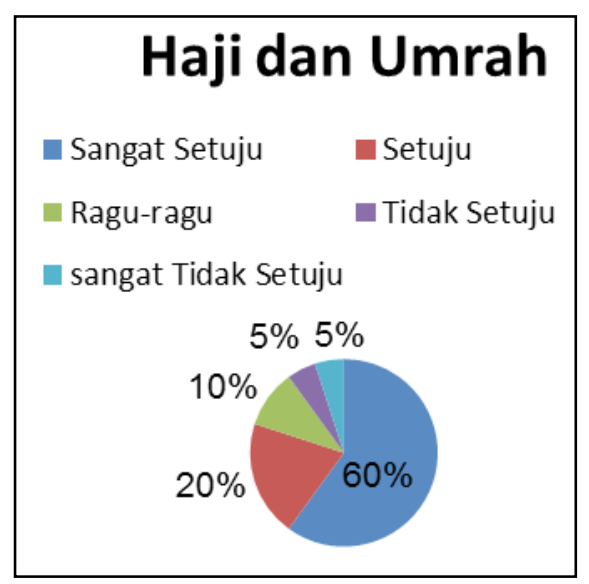

Mereka yang $60 \%$ dan $20 \%$ adalah bias membedakan antara umtrah dan haji.bagi mereka haji adalah dilaksanakan pada bulan tertentu yakni bulan haji dan pelaksanaannya berebda dengan umrah. Umrah tida ada wukuf di Arafah. 
Sementara wukuf Arafah inilah yang menjadikan perbedaan haji dan umrah. Dengan pemahaman ini, maka sosok PERSIS atas pelaksanaan ibadah haji dan umrah dapat membedkan dengan baik. Sementara sebanyak 20\% di dalamnya yang terinci tidak tahu $10 \%$ dan selebihnya tidak mengerti sebanyak $10 \%$ hal ini disebabkan mereka ini baru melaksanakan ibadah umrah sekali dan sebgian di antaranya juga akan melaksanakan umrah. Mereka memahami konteks ibadah umrah disbanding dengan haji. Namun, bagi mereka yang sudah melaksanakan haji, maka pemahaman mereka lebih bagus dalam membedakan antara umrah dan haji.

Terkait erat dengan pelaksanaan ibadah di Arab Saudi, maka jamaah KBIH PERSIS kebanyakan memberikan arti pentingnya $\mathrm{KBIH}$ dalam pelaksanaan ibadah haji atau umrah. Hal ini tergambar sebagai berikut:

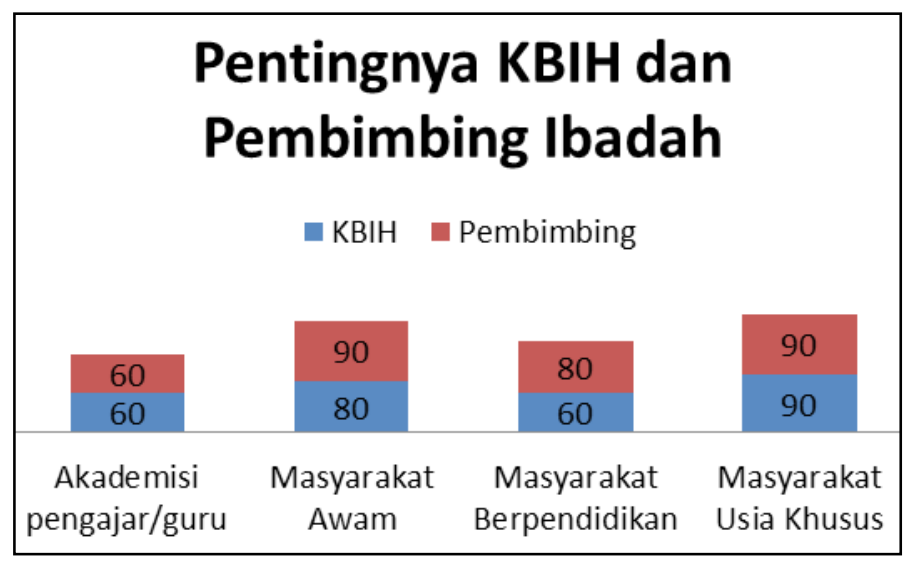

Terdapat empat kluster dalam hal ini, bagi akademisi yang terdiri atas pengajar/guru, masyarakat awam, masyarakat yang berpendidikan dan masyarakat usia khusus di mana mereka ini di atas usia 60 tahun. Dari keempat kluster tersebut maka masyarakat yang usia khusus ini sangat terbantu oleh KBIH dan pembimbing. Sebagian besar mereka menginginkan untuk suksesnya ibadah haji dan umrah dengan adanya bimbingan. Hal tersebut berbanding terbalik dengan mereka yang berpendidikan baik guru atau yang lainnya akademisi. Mereka ini lebih mandiri ketimbang mereka yang suia tua dan masyarakat yang awam. Karena kedua profil masyarakat awam dan masyarakat berkebutuhan khusus karena tua, sakit dan usia di aas 60 tahun, maka peranan KBIH dan pembimbing menjadi sangat penting.

Hal ini dapat dimaklumi, jika mereka melaksanakan ibadah haji sendirian atau bersama suami isteri namaun sudah memilki kebutuhan khusus, maka mereka lebih banyak menjadikan KBIH dan pembimbing dalam pelaksanaan 
ibadah haji, hal ini berbeda dengan mereka yang maish muda dan memiliki pengetahuan. Sehingga, dalam pelaksanaannya mereka yang berpendidikan dan memiliki pengetahuan dapat dijadikan sebagai modal dalam perjalanan ibadah haji. Mereka ini setidaknya dapat dijadikan sebagai pemimpin atau ketua rombongan dan ketua regu sehingga satu jamaah lain dengan yang lain saling membantu sesuaia dengan kebutuhannya masing-masing.

Sementara terkait erat dengan pelaksanaan ibadah melempar jumrah. Mereka jamaah haji PERSIS semuanya sesuai dengan ajaran yang dikembangkan dalam organisasi yakni mereka lebih cenderung sesuai dengan yang dicontohkan oleh Nabi saw. hal yang dicontohkan oleh Nabi saw. adalah melaksanakan leper jamarat di waktu tergelincirnya matahari. Adapun ragam pemahaman yang ada adalah:

\section{Pemahamanan Lempar Jamarat}

- Sangat Setuju Sesuai Anjuran Nabi saw.

- Setuju Sesuai Aturan Nabi saw.

- Ragu-ragu

- Tidak Setuju Sesuai Tuntunan Nabi saw.

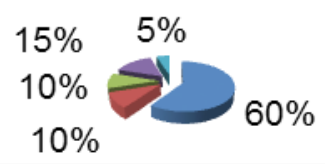

Sebagian besar setuju dengan apa yang dilaksanakan oleh Nabi saw. dan hanya $30 \%$ mereka yang ragu ragu dan tidak melaksanakan sesuai yang dilaksanakan Nabi saw. bagi mereka, yang 30\% ini melaksanakan jamarat adalah dapat dilaksanakan sesuai dengan jadwal yang diberikan oleh pemerintah Arab Saudi. Baginya, sebagaimana terjadi dalam kasus-kasus jamarat yang sering terjadi, maka kenyamanan dan keamanan adalah lebih utama. Oleh karena itu, mereka ini lebih cenderung tidak sesuai dengan kebanyakan pengikut $\mathrm{KBIH}$ PERSIS ini.

Mereka ini yang cenderung lebih taat kepada Nabi saw. dalam hal melempar jamarat adalah mereka yang militant dalam memahami ajaran agama Islam sesuai dengan koridor pemahaman yang diperoleh dari para pendahu PERSIS. Mereka ini adalah dalam usia masih muda dan secara fisik dapat menjalankan kegiatan dengan prima. Hal ini berbeda dengan mereka yang sudah 
senioar dan cenderung secara fisik kurang dapat menjalankan kegiatan secara maksimal kegiatan fisik.

Haji sebagai kegiatan fisik. Menurut kebanyakan jamaah PERSIS adalah membutuhkan kesehatan yang prima terutama kegiatan utama haji, yakni melaksanakan wukuf di Arafah dan wajib haji lainnya. Demikian juga atas kegiatan lain seperti mabit di Muzdalifah dan melempar jamarat di Mina. Kegiatan haji ini diakhiri dengan tawaf ifadhah yang juga dilakukan secara bersama-sama, sehingga memungkinkan banyaknya jamaah haji yang kelelahan dalam melaksanakannya.

Oleh sebab itu, dalam pandangan pengelolaan manajemen haji yang baik dan prima, maka diperlukan kesadaran dari semua pihak termasuk jamaah haji dan para pemimpin $\mathrm{KBIH}$ dalam melaksanakannya harus disesuaikan dengan jadwal yang ada untuk menghindari penumpukan banyak jamaah dan kenyamanan dalam melaksanakan ibadah.

Hal di atas menjadikan suatu keharusan dalam melaksanakan ibadah haji. Gambaran pemahaman baru atas pelaksanaan ibadah haji dapat dlihat sebagai berikut.

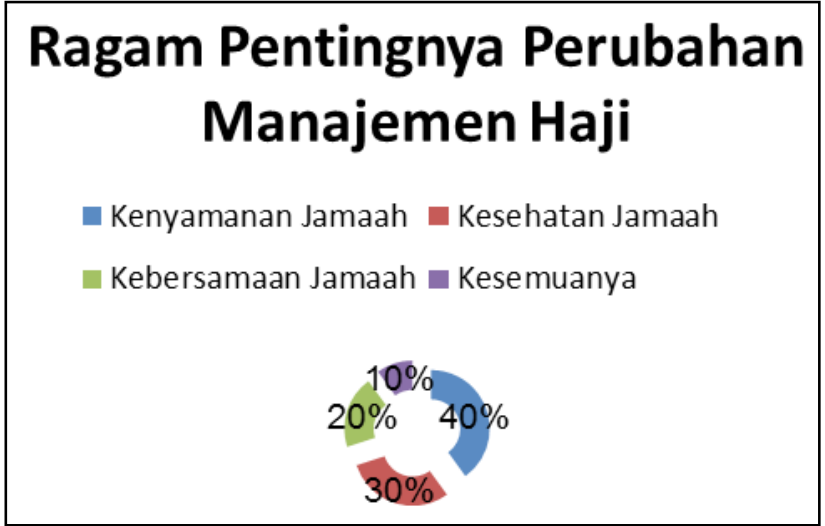

Dari tabel di atas Nampak bahwa aturan-aturan yang dikenakan kepada jamaah haji dalam rangka untuk jamaah haji secara keselusuhan. Mereka ini yakin apa yang dilakukan adalah dalam komntkes kenyamanan untuk jamaah, kesehatan jamaah haji, dan kebersamaan jamaah haji. Namun, pada intinya adalah untuk kenyamanan jamaah haji. Sehingga, dalam menjalankan ibadah haji jika ada kenyamanan akan menjalankan dengan baik dan dapat sesuai dengan yang dicontohkan Nabi saw.

Bagi sebagian jamaah, dengan banyaknya jumlah jamaah haji, maka dituntut untuk menjadikan haji untuk kebaikan dalam menjalankan ibadah 
dan kembali ke tanah air dengan sahat dan dapat menjadikan spirit haji dalam kehidupan kesehariannya. Tentunya, jumlah masyarakat yang berhaji tidak seramai atau sebanyak pada zaman dahulu, maka dituntut arif dan bijaksana dalam menjalankan ibadah haji dengan aturan-aturan yang disepakati dengan pemerintah Arab Saudi dan Indonesia. Sehingga tujuan haji akan dapat terlaksana dengan baik.

Mereka yang melaksanakan ibaah haji semuanya ingin kembali ke tanah air dan dapat menjalankan spirit ibadah haji dalam kehidupan kesehartiannya. Adapun gambaran umumnya adalah:

\section{Motivasi Sepulang Haji}

Menjalankan Ibadah lebih Baik

- Melaksanakan semua ibadah

Diampuni semua dosa-dosanya

Menjadi Jaminan Surga

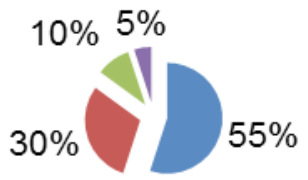

Rata-rata kebanyakan jamaah haji sepulang haji akan menjadikan pribadinya sebagai pribadi yang baik dengan melaksanakan ibadah-ibadah lainnya dnegan baik. Bahkan di antara mereka ingin melaksanakan ibadah lainnya yang tidak hanya ibadah mahdhah yakni dengan melaksanakan ibadah sadaqah dan zakat yang hubungannya dengan harta benda. Hanya sedikit sekali yang berkeinginan sepulang haji akan diampuni dosa-dosanya dan yang mendapatkan surga dari Allah swt.

Bagi mereka yang menginginkan perubahan ibadah yang baik tentunya sudah jelas bahwa mereka yang dituju adlaah ridha Alah swt. sedangkan keridhaan tersebut akan mengantarlkan kepada kebahagiaan di akhirat yang tergambrkan dengan surga Allah swt. sebagaimana yang sudha dijanjikan melalui hadis-hadis Nabi saw

Diriwayatkan dari Abu Hurairah r.a., bahwa Rasulullah Saw. pernah bersabda: "'umrah yang satu dengan 'umrah berikutnya adalah penghapus dosa yang 
dilakukan antara masa keduanya, sedangkan haji mabrur balasannya tiada lain adalah surga." ${ }^{28}$

Pahala lain dari haji adalah pengampunan dosa-dosa dari pelakunya. Garansi ini adalah khusu bagi mereka yang melaksnaakan haji degan ketulusan hati yakni dengan tidak melakaukan perbuatan yang keji, tidak melakukan rafas dan hal-hal yang menuju kefasikan. Sebagaimana hadis berikut:

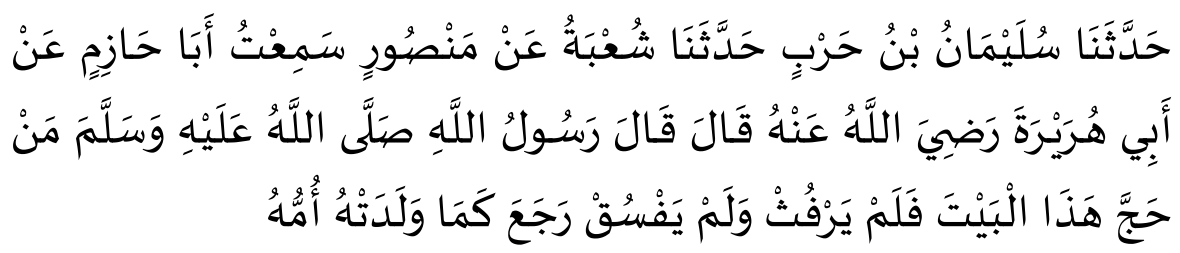

"Diriwayatkan dari Abu Hurairah r.a., ia berkata: Rasulullah Saw. pernah bersabda: "Barangsiapa berhaji ke Baitullah tanpa berkata keji, tanpa bersetubuh dan tanpa berbuat kefasikan (selama ihram), maka dia pulang (tanpa dosa) bagaikan bayi yang baru lahir." 29

Khusus bagi perempuan, Nabi saw. memberikan penjelasan bahwa sebaikbaik jihad perempuan adalah haji. Tidak seperti kaum laki-laki yang melakukan jihad di medan perang atau jihad dalam bentuk lainnya. Bagi perempuan, ibadah haji sebagaimana dikatakan oleh Nabi Muhammad saw. yang menyatakan bahwa haji adalah jihad adalah benar adanya karena haji adalah ibadah fisik. Dengan sejumlah jutaan ummat manusia yang menjalankan ibadah haji menjadikan ibadah ini sebagai bentuk perjuangan di antara ummat Islam. Mereka menjalankan ibadah haji tidak secara mudah melainkan dengan perjuangan yang dilakukan secara fisik dengan melantunkan sejumlah kalimat tayyibah.

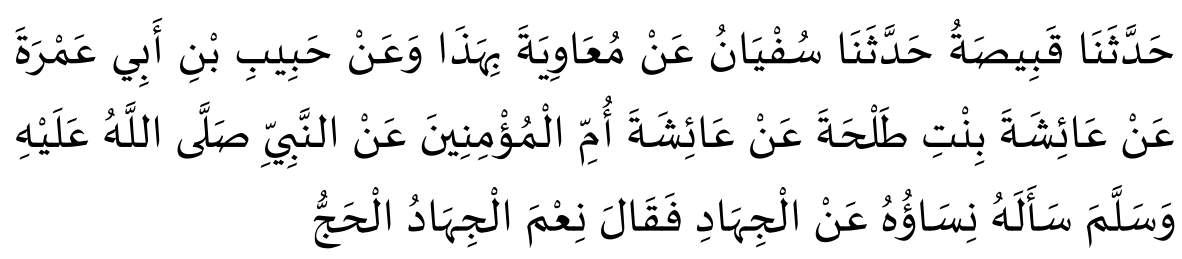

${ }^{28}$ Shahih Al-Bukhari, al-Hajj No. 1650, Shahih Muslim, al-Hajj No. 2403, Sunan al-Tirmizi, al-Hajj an Rasulillah, No. 755, Sunan Nasa'i Manasik al-Hajj, No. 2575, 2576, 2582, 2878, Sunan Ibnu Majah, al-Manasik, No. 2878, Musnad Ahmad, No. 7050, 9562, 9569, Muwattha' Malik, alHajj, No. 675, dan Sunan al-Darimi, No. 1728

${ }^{29}$ Hadis ini juga diriwayatkan padaShahih Al-Bukhari, Bab al-Hajj, No. 1819, Shahih Muslim, Bab Hajj No. 2404, Sunan al-Tirmizi, al-Hajj an Rasulillah No. 739, Sunan al-Nasa'I, Bab Manasik alHajj No. 2580, Sunan ibnu Majah, al-Manasik No. 2880, Musnad Ahmad, No. 6839, 7077, 8943, 9885, 10006, Sunan al-Darimi, al-Manasik 1728. 
"Dari Aisyah, ummul müminin r.a. dari Nabi saw. bahwa para istri Beliau bertanya kepada Beliau tentang jihad, maka Beliau bersabda: «Sebaik-baik jihad (bagi kaum wanita) adalah haji" ${ }^{30}$

Tentunya, semangat pasca haji ini mereka lakukan untuk senantiasa melakukan yang terbaik dalam kehidupannya di dunia. Ini meurpakan paripurna tujuan utama masyarakat dalam melaksanakan ajaran Islamnya termausk di dalamnya adalah ibadah haji. Slaah satu hal yang menarik adalah sepulang haji mereka merasa dapat melaksanakan ibadah dengan baik dan dengan memberikan kelebihan rizki yang dimiliki untuk kebahagiaan bersama sesama muslim.

\section{Kesimpulan}

Dari penjelasan di atas dapat disimpulkan bahwa pemahaman manasik haji bagi PERSIS merupakan sesuatu yang penting. Hal ini terlihat dari pentingnya contoh tauladan dari Nabi Muhammad saw. Di antara jamaah menjadikan pentingnya hal tersebut sehingga dalam menjalankan ibadah haji dan manasiknya harus sesuai dengan apa yang dicontohkan oleh Muhammad saw. Hal tersebut juga didukung dengan pengetahuan mereka atas prosesi pelaksanaan haji yang memerlukan kegiatan fisik. Peranan KBIH dalam memberikan pengetahuan jamaah haji sangat penting karena sebagian besar jamaah haji belum pernah melaksanakan ibadah haji dan umrah. Dan juga sebagian besar mereka tidak pernah mengenyam pendidikan sampai ke jenjang yang tinggi. Ragam pemahaman atas manasik dan pengalaman dari pembimbing dalam mengarahkan harus disampaikan sesui pengalaman mereka. Sehingga, jamaah haji akan mendapatkan pengetahuan sesuai dengan kenyataan yang sesungguhnya. Oleh sebab itu, pentingnya perubahan manajemen haji yang dapat menjadikan pelaksanaan ibadah haji berjalan nyaman dan jamaah dapat pulang dengan selamat dan sehat.

\footnotetext{
${ }^{30}$ Shahih Bukhari Bab Jihad wa al-Siyar, No. 2664. Sunan Ibnu Majah, al-Manasik, No. 2892 dan Sunan al-Nasa'I, Manasik Haji No. 2581. 


\section{DAFTAR PUSTAKA}

Ahimsa-Putra, Heddy Shri. "Menafsir 'al-Qur'an yang Hidup', Memaknai alQur'anisasi Kehidupan: Perspektif Antropologi Budaya”, Makalah Seminar "Living Qur'an: Al-Qur'an sebagai Fenomena Sosial Budaya”, Yogyakarta. 2005.

Arsy, Yusuf. (ed.) Gerakan Dakwah Islam dalam Perspektif Kerukunan Ummat Beragama. Badan Litbang dan Diklat Keagamaan Kemenag RI. 2012.

Ayyub, Muhammad. "Konflik dan integrasi: analisis terhadap peamahaman Keagamaan Kelompok Persatuan Islam (Persis) dan Nahdlatul Ulama (NU): Studi Kasus Masyarakat Kelurahan Mekarsari Depok Jawa Barat”. Skripsi Fisipol UIN Syarif Hidayatullah Jakarta. 2011.

Hamid, Abdul. "Kemungkinan Haji di Luar Bulan Zulhijjah dalam Perspektif Qat'i dan Zanni”. Jurnal Penelitian. Vol. 11 No. 1.2014.

Koswara, Iwan. "Eksistensi Persatuan Islam dalam Penyebaran Paham Keagamaan” Jurnal Academia”. Vol. 10. No. 2. 2014.

Nanang Sutrisna, "Persatuan Islam (Persis) pada Masa KH. E. Abdurrahman (1962-1983)”. Skripsi, Fak. Adab UIN Sunan Kalijaga Yogyakarta. 2008.

Ningsih, Ika Setia. "Pengaruh Latihan Senam Haji terhadap Peningkatan Daya Tahan Jantung dan Paru pada Calon Jamaah Haji Non Resiko Tinggi”. Jurnal Fisioterapi Indonusa. Vol. 5 No. 2. 2005.

Padmo, Soegijanto. "Gerakan Pembaruan Islam Indonesia dari Masa ke Masa: Sebuah Pengantar”. Jurnal Humaniora. Vol. 19. No. 2. 2007.

Rahman, Fazlur. Islamic Methodology in History. Karachi: Central Institute of Islamic Research. 1965.

Rahman, Fazlur. "Concept Sunnah, Ijtihad and Ijma' in the Early Period”. Islamic Studies, Vol. 1. No. 1. 1962.

Soekanto, Soerjono. Sosiologi Suatu Pengantar. Jakarta: RajaGrafindo Persada. 2002.

Suharto, Toto. "Kesadaran yang Bertentangan sebagai Bentuk Resolusi Konflik dalam Pendidikan: Pengalaman Pesantren Persatuan Islam di Masa Orde Baru”, Jurnal Analisis, Vol. XII No. 2. 2012.

Sulaiman, "Kepuasan Jamaah Haji terhadap Pelayanan KBIH di Kabupaten Jepara”. Jurnal Analisa. Vol. 21. No. 1.2013. 
Sultoni, M. "Haji dan Kegairahan Ekonomi: Menguak Makna Ibadha Haji bagi Pedagang Muslim di Yogyakarta”. Jurnal Penelitian. Vol. 9 No. 1. 2012.

Yuliana, Siti. Peranan Departemen Agama dalam Penyelenggaran Ibadah Haji Kabupaten Madiun: Studi Deskriptif Kualitatif tentang peranan Departemen Agama dalam tahun penyelenggaraan haji tahun 2007/2009. Skripsi, Fispol, Universitas Sebelas Maret 2009.

Kutub al-Sittah, Mawsuat al-Hadis al-Syarif. 